\title{
ON THE EFFECTS OF SOME CARCINOGENIC HYDROCARBONS ON THE GROWTH OF SPORELINGS OF MARINE RED ALGAE
}

\author{
By A. D. BONEY \\ Department of Chemistry and Biology, Plymouth College of Technology
}

AND E. D. S. CORNER

The Plymouth Laboratory

From the vast accumulation of literature on cancer recent reviews have appeared stressing that this problem should not be regarded as simply another aspect of medical research, but as a general biological phenomenon (Huxley, I956, I957, 1958). There is, however, comparatively little information about cancer in species other than mammals; and as far as plants are concerned most of the few studies which have been made have centred on crown gall tumours produced in angiosperms by Agrobacterium tumiefasciens (vide White, 195I; Braun, 1957).

Since Kennaway (1924) showed that a pure polycyclic hydrocarbon could induce skin tumours in animals, many hundreds of chemicals with this property (carcinogens) have been and are being discovered, some of which may be encountered in daily life (e.g. 3,4-benzpyrene). So far, however, very little is known about the effects of carcinogens on plants. Thomas, Evans \& Hughes (1956) induced neoplasms in certain Basidiomycetes by exposure of the thalli to Diesel-oil vapour, exhaust and tar fumes; Mottram (I944) studied the effects of 3,4-benzpyrene on the mitotic behaviour of cells of bean roots; and Levine (1950) observed that I,2,5,6-dibenzanthracene, 3,4-benzpyrene and 20-methylcholanthrene stimulated the growth of carrot root meristems in tissue culture, but did not consider this effect to be a criterion for malignancy.

Recently we have used measurements of the growth and viability of sporelings of red algae in studies of the effects of various environmental factors on the plants (Boney, I960; Boney \& Corner, I959, I960, 1962). In the species principally examined the rate of development of the very young sporeling is controlled by the activity of a single apical meristematic cell. This activity results in the formation of an erect filament of cells on which lateral branches appear once the filament has attained a certain length. Measurements of the overall cell production of sporeling populations can thus be used to study the effects of stimulatory and inhibitory substances on the apical meristematic cells, and it seemed to us that measurements of this kind might be investigated as a possible means of providing a quick and reliable biological 
assay for various carcinogens. Results with certain polycyclic hydrocarbons support this view.

We are indebted to Dr W. Carruthers of the Carcinogenic Substances Research Unit (University of Exeter) and to Dr R. D. Bulbrook of the Imperial Cancer Research Fund Laboratories (Royal College of Surgeons) for supplying us with a number of polycyclic hydrocarbons; and one of us (A.D.B.) gratefully acknowledges a grant from the Medical Research Council enabling us to secure the valuable technical assistance of $\mathrm{Mr} \mathrm{G}$. M. Hacking.

\section{METHODS}

Culture medium. Sea water collected from outside Plymouth Breakwater was filtered through a Berkefeld Candle, and then enriched with nitrate and phosphate $(0.2 \mathrm{~g}$. $\mathrm{NaNO}_{3}$ and $0.03 \mathrm{~g} . \mathrm{Na}_{2} \mathrm{HPO}_{4} \cdot \mathrm{I}_{2} \mathrm{H}_{2} \mathrm{O} / \mathrm{l}$.). To this were added trace elements and EDTA in the concentrations used for Droop's S 20 medium (Droop, 1955). In a number of trial experiments it was found that this medium supported a growth of sporelings as healthy as that observed in earlier studies with 'Plymouth' Erd-Schreiber medium (Boney \& Corner, 1962).

Carcinogen solutions. All the carcinogens under test were insoluble hydrocarbons, and it was difficult to apply these to the sporelings in sea water. The method finally used was to prepare $0.1 \%$ solutions in methyl cellosolve (which had no toxic effect on the sporelings in the concentrations used in the experiments) and to add an appropriate aliquot to the culture medium just before the experiment was started. In this way the sporelings were treated with the carcinogen as a fine colloidal suspension at a known concentration in sea water.

Culture apparatus and conditions of experiment. Slides bearing the sporelings were placed at a steep angle in culture medium ( $120 \mathrm{ml}$.) contained in glass vessels with plastic caps. The culture vessels were kept in a constant temperature room $\left(16^{\circ} \mathrm{C}\right)$ at a measured distance from a Mazda 'Daylight' fluorescent strip. Details of optimum light energy measurements may be found elsewhere (Boney \& Corner, 1962). All glassware used in the experiment was thoroughly rinsed with tap water after use, treated overnight with chromic acid, rinsed 20 times with tap water and then with glass-distilled water before being used again.

\section{RESULTS}

\section{Experiments with Antithamnion plumula (Ellis) Thur.}

Cell production by sporelings of Antithamnion plumula treated with various carcinogenic hydrocarbons is shown in Table I. It will be seen that all four compounds tested caused a significant increase in growth. Thus, compared with that of the untreated material, cell production by sporelings immersed for 4 days in sea water containing 20-methylcholanthrene at a concentration of $0.0 \mathrm{I} \mathrm{mg} / \mathrm{l}$. was practically doubled; the growth of material treated with the same concentration of 9,10-dimethyl-I,2-benzanthracene was increased even more; and a large stimulus of growth was observed with 6-methyl-I,2-benzanthracene at both this concentration and at $0.1 \mathrm{mg} / 1$. Similar but less marked 
results were obtained with 3,4-benzpyrene. In these experiments, solutions of carcinogen were prepared freshly each day and the sporelings remained in constant contact with low concentrations of carcinogen throughout an experimental period of four days. However, in some further experiments with 20-methylcholanthrene the method of application was changed, the sporelings being dipped for much shorter periods $(0.5-1 \mathrm{~h})$ in sea water containing much

TABLE 1. EFFECT OF CERTAIN POLYCYCLIC AROMATIC HYDROCARBONS ON CELL PRODUCTION BY SPORELINGS OF ANTITHAMNION PLUMULA (Sporelings immersed for measured times in sea water containing fine suspensions of carcinogens added as known concentrations in methyl cellosolve. Figures in final column include standard deviations based on four determinations.)

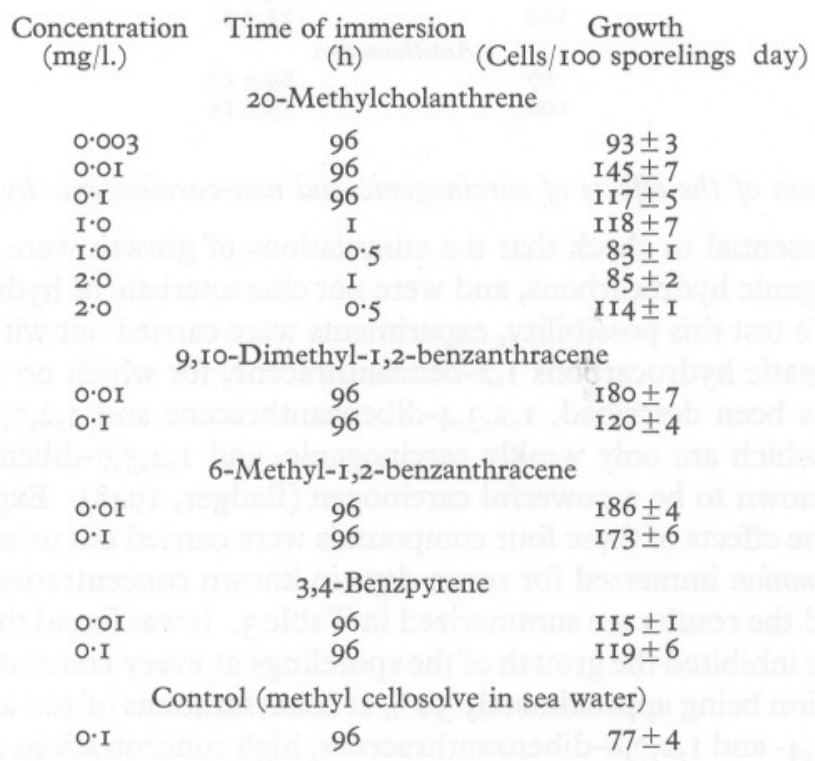

higher concentrations of carcinogen ( $\mathrm{I}-2 \mathrm{mg} / \mathrm{l}$.) then returned to fresh culture medium and examined after 7 days. The results of these experiments are included in Table $\mathrm{I}$ and again show a significant increase in the rate of growth of the treated sporelings.

\section{Experiments with other species}

Similar experiments with 20-methylcholanthrene were carried out using sporelings of Spermothamnion repens (Dillw.) Rosenv. and Callithamnion tetricum Ag. The results shown in Table 2 confirm the earlier findings with $A$. plumula in that once again a measurable increase in growth was observed when sporelings were treated with the hydrocarbon. However, with neither species was the stimulus so well marked as in experiments with Antithamnion. 
TABLE 2. EFFECT OF 20-METHYLCHOLANTHRENE ON CELL PRODUCTION BY SPORELINGS OF SPERMOTHAMNION REPENS, CALLITHAMNION TETRICUM AND ANTITHAMNION PLUMULA

(Sporelings immersed 4 days in sea water containing a fine suspension of 20 -methylcholanthrene added as a known concentration in methyl cellosolve. Figures in right-hand column include standard deviations based on four determinations.)

\begin{tabular}{|c|c|}
\hline $\begin{array}{c}\text { Concentratior } \\
(\mu \mathrm{g} / 1 .)\end{array}$ & $\begin{array}{l}\% \text { Stimulus of cell } \\
\text { production }\end{array}$ \\
\hline \multicolumn{2}{|c|}{ Spermothamnion } \\
\hline 10 & $\begin{array}{ll}23 \pm I \\
28 \pm T\end{array}$ \\
\hline \multicolumn{2}{|c|}{ Callithamnion } \\
\hline IO & $24 \pm 2$ \\
\hline 100 & $2 I \pm I$ \\
\hline \multicolumn{2}{|c|}{ Antithamnion } \\
\hline I0 & $89 \pm 17$ \\
\hline 100 & $55 \pm 15$ \\
\hline
\end{tabular}

\section{Comparison of the effects of carcinogenic and non-carcinogenic hydrocarbons}

It was essential to check that the stimulations of growth were caused only by carcinogenic hydrocarbons, and were not characteristic of hydrocarbons as a whole. To test this possibility, experiments were carried out with the pentacyclic aromatic hydrocarbons I,2-benzanthracene, for which no carcinogenic activity has been described, I,2,3,4-dibenzanthracene and I,2,7,8-dibenzanthracene, which are only weakly carcinogenic, and I,2,5,6-dibenzanthracene which is known to be a powerful carcinogen (Badger, 1948). Experiments to compare the effects of these four compounds were carried out using sporelings of Antithamnion immersed for seven days in known concentrations of hydrocarbon and the results are summarized in Table 3 . It was found that I,2-benzanthracene inhibited the growth of the sporelings at every concentration used, the inhibition being approximately $50 \%$ at concentrations of 100 and $300 \mu \mathrm{g} / 1$. With I,2,3,4- and I,2,7,8-dibenzanthracenes, high concentrations again caused measurable growth inhibitions, but at a low concentration (I0 $\mu \mathrm{g} / 1$.) there was some evidence of a small stimulation of growth, $15 \%$ with $1,2,3,4-$ and $20 \%$ with I,2,7,8-dibenzanthracene. Finally, when I,2,5,6-dibenzanthracene was used, although growth of the sporelings was again inhibited at high concentrations $(300 \mu \mathrm{g} / 1$.$) , there was now a marked stimulus of growth when lower$ concentrations were used ( $56 \%$ at $10 \mu \mathrm{g} / 1$. and $35 \%$ at $30 \mu \mathrm{g} / 1)$.

Although the effects of these various hydrocarbons on growth vary greatly with the concentration used, the experiments with very low concentrations of the compounds clearly demonstrate that the carcinogenic activities of the benzanthracene derivatives do in fact correlate with ability to stimulate the growth of red algal sporelings. Nevertheless, it is obviously desirable to investigate this important aspect of the work with a much larger range of carcinogens and non-carcinogens and further experiments along these lines 
are already in progress with sporelings of Plumaria elegans (Bonnem.) Schm. Findings so far (to be reported in a later paper) confirm the above results with Antithamnion. In passing it must be noted that of all the compounds used, the benzanthracene derivatives were the most difficult to disperse in the culture medium, and inconsistencies were also encountered in earlier experiments because the compounds crystallized out of the stock solutions. It was essential to prepare these freshly for every experiment.

TABLE 3. EFFECTS OF VARIOUS DERIVATIVES OF BENZANTHRACENE ON CELL PRODUCTION BY SPORELINGS OF ANTITHAMNION PLUMULA

(Conditions of experiment as described in text. Results for each compound shown as cells/100 sporelings/day, and include standard deviations based on four determinations.)

\begin{tabular}{|c|c|c|c|c|c|}
\hline \multirow[b]{2}{*}{ Compound } & \multicolumn{5}{|c|}{ Concentration $(\mu \mathrm{g} / 1)}$. \\
\hline & ० & IO & 30 & 100 & 300 \\
\hline I,2-Benzanthracene & $148 \pm 6$ & $123 \pm 7$ & $108 \pm 3$ & $73 \pm 3$ & $73 \pm I$ \\
\hline $1,2,3,4$-Dibenzanthracene & $148 \pm 6$ & $170 \pm 5$ & $122 \pm 2$ & $98 \pm 2$ & $47 \pm 2$ \\
\hline $1,2,7,8$-Dibenzanthracene & $148 \pm 6$ & $179 \pm 2$ & $135 \pm 7$ & $105 \pm 8$ & $82 \pm 5$ \\
\hline I,2,5,6-Dibenzanthracene & $148 \pm 6$ & $230 \pm 5$ & $20 I \pm 3$ & $150 \pm 2$ & II $7 \pm 4$ \\
\hline
\end{tabular}

The results obtained in the present series of experiments have shown that actively growing algal cells are influenced by contact with certain carcinogenic compounds, and as a result divide at a faster rate than cells of control material. In this respect our results verify the few other observations made on the effects of carcinogenic agents on meristematic cells. However, although there are indications in the present work that this effect is due to contact with aromatic hydrocarbons which are of a carcinogenic nature, and does not occur when structurally related non-carcinogens are applied, there are at present many hundreds of compounds listed as possessing some degree of carcinogenic activity. The value of any screening test must therefore lie in its overall applicability, as well as in the recognition that some effect on the growth mechanism of the test material is specifically due to the action of a carcinogen. This will clearly call for tests on many compounds showing different types of carcinogenic activity, and we are at present carrying out screening tests on some sixty compounds selected from as wide a range as possible, includingfor purposes of comparison-numerous compounds for which no carcinogenic property is recorded.

The filamentous mode of development characteristic of the test species allows a direct measure to be made of the rate of division of the apical meristematic cell. Although the degree of somatic organization of the test material is low in the evolutionary scale compared with the higher plants on which tests have earlier been reported, the polarity of the sporeling is clearly differentiated early in its development. The carcinogen thus influences the whole plant through its effect on the rate of division of the apical cell-the 'pace-setter' for 
the early development of the sporeling. However, the principal characteristic of the effect of a carcinogen on animal cells is its power of inducing autonomous growth with the subsequent formation of a neoplasm. In plants such a growth has been obtained only with crown-gall tumour. No indications of any autonomous growth has been observed in the present work, even when the plant material has been kept in contact with a carcinogen for several weeks. However, there are clear indications in the results so far obtained that the carcinogens are toxic at certain concentrations, and so the mode of application becomes a major problem in studies of the effects of such compounds.

Although the carcinogens may stimulate the growth of the sporelings, it is of considerable importance to know whether the cells produced under the influence of a carcinogen are in any way abnormal when compared with untreated cells. From their appearance on microscopic examination no differences can be seen between cells of sporelings treated with carcinogens and those of the untreated controls. There is, however, the possibility that this enhanced growth results in some metabolic abnormality, and certain aspects of this problem are also being investigated as part of a general study of the effects of biologically active compounds on sporeling growth.

\section{SUMMARY}

Low concentrations of various carcinogenic polycyclic aromatic hydrocarbons cause a considerable increase in cell production when applied to sporelings of certain marine red algae.

Whereas low concentrations of carcinogenic derivatives of benzanthracene stimulate cell production, similar concentrations of structurally related noncarcinogens inhibit it.

The applicability of the method as a rapid screening test for carcinogens is discussed.

\section{REFERENCES}

BADGER, G. M., I948. The carcinogenic hydrocarbons: chemical constitution and carcinogenic activity. Brit. F. Cancer, Vol. 2, pp. 309-50.

BoneY, A. D., 1960. Nurture of a fruiting Antithamnion tuft and the physiological condition of the liberated spores. Brit. phycol. Bull., Vol. 2, pp. 38-9.

BONEY, A. D. \& CoRNER, E. D. S., 1959. Application of toxic agents in the study of the ecological resistance of intertidal red algae. F. mar. biol. Ass. U.K., Vol. 38, pp. 267-75.

- 1960. A possible function of phycoerythrin in intertidal red algae. Nature, Lond., Vol. I88, pp. 1042-3.

- 1962. The effect of light on the growth of sporelings of the intertidal red alga Plumaria elegans (Bonnem.) Schm. F. mar. biol. Ass. U.K., Vol. 42, pp. 65-92.

BRAUN, A. C., I957. A physiological study on the nature of autonomous growth in neoplastic plant cells. Symp. Soc. exp. Biol., No. II, pp. I32-42.

Droop, M. R., 1955. Some new supra-littoral Protista. F. mar. biol. Ass. U.K., Vol. 34, pp. 233-45. 
HuXley, Julian, 1956. Cancer biology: comparative and genetic. Biol. Rev., Vol. 31, pp. 474-5I4.

- 1957. Cancer biology: viral and epigenetic. Biol. Rev., Vol. 32, pp. I-37.

- 1958. Biological Aspects of Cancer. 156 pp. London: Allen and Unwin.

Kennaway, E. L., 1924. Cancer-producing tars and tar fractions. F. indust. Hyg., Vol. 5, pp. $462-88$.

Levine, M., I950. The growth of normal plant tissue in vitro as affected by chemical carcinogens and plant growth substances. I. The culture of the carrot tap-root meristem. Amer. F. Bot., Vol. 37, pp. 445-8.

Mottram, J. C., I944. Production of 'Endomitosis' in bean roots and its bearing on the genesis of tumours. Nature, Lond., Vol. I54, p. 828.

Thomas, P. T., Evans, H. J. \& Hughes, D. T., 1956. Chemically induced neoplasms in Fungi. Nature, Lond., Vol. 178, pp. 949-51.

White, P. R., I95I. Neoplastic growth in plants. Quart. Rev. Biol., Vol. 26, pp. I-I6. 